\title{
Parallel synthesis of arrays of 1,4,5-trisubstituted 1-(4-piperidyl)- imidazoles by IMCR: a novel class of aspartyl protease inhibitors**
}

\author{
Alexander Dömling, ${ }^{1}$ Barbara Beck, ${ }^{1,2}$ Eberhardt Herdtweck, ${ }^{3}$ Walfrido Antuch, \\ Christian Oefner, ${ }^{2}$ Nasser Yehia, ${ }^{2}$ and Adoračion Gracia-Marques ${ }^{2}$ \\ ${ }^{1}$ Department of Pharmaceutical Sciences, University of Pittsburgh, Pittsburgh, Pennsylvania \\ 15260, USA; ${ }^{2}$ Morphochem AG, Gmunder Str. 37-37a, 81379 München, Germany; \\ ${ }^{3}$ Technical University Munich, Lichtenbergstr. 4, D-85747 Garching b. München, Germany \\ E-mail: asd30@pitt.edu
}

\section{Dedicated to the $80^{\text {th }}$ birthday of Madeleine M. Joullié}

\begin{abstract}
The synthesis of a novel class of potential aspartyl-protease inhibitors is described. Arrays of 1,4,5-trisubstituted 1-(4-piperidyl)-imidazoles have been assembled by parallel synthesis using an isocyanide-based multi component reaction (vL-3CR).
\end{abstract}

Keywords: Aspartyl protease inhibitor, van Leusen, isocyanide, IMCR

\section{Introduction}

Enzymes that hydrolyse proteins and peptides are called proteases. They are critical to all normal and pathological events and are often important targets for therapeutic interventions. Amongst the four classes of proteases (serine/threonine, metallo, aspartyl, cystein) the aspartyl proteases comprise the smallest class of proteases in the human genome. However, prominent medicinally relevant examples of the aspartyl-protease family are renin (cardiovascular diseases), ${ }^{1} \mathrm{HIV}$ protease (AIDS), ${ }^{2} \beta$ - and $\gamma$-secretase (Alzheimer), ${ }^{3}$ Candida albicans asp-protease (fungal infection), ${ }^{4}$ cathepsin D (cancer) ${ }^{5}$ and plasmepsin $1 / 2$ (malaria). ${ }^{6}$ Despite the fact that aspproteases are the smallest group of proteases, the largest number of their inhibitors is used therapeutically. Currently 8 asp-protease inhibitors are on the market and several more are under advanced clinical evaluation (Figure 1). 


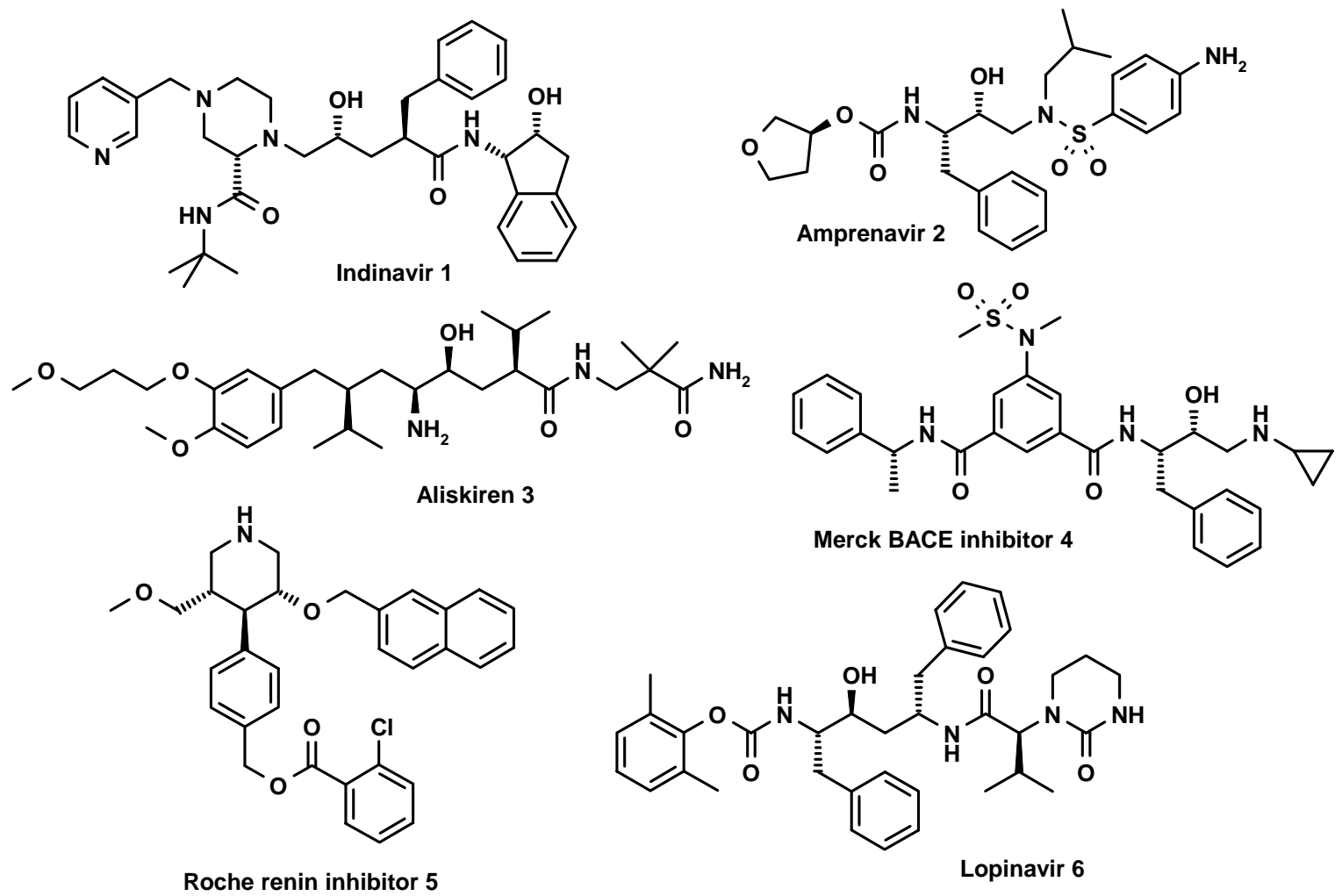

Figure 1. Representative small molecular weight asp-protease inhibitors. Indinavir 1, Amprenavir $\mathbf{2}$ and Lopinavir $\mathbf{6}$ are HIV protease inhibitors, whereas Aliskiren $\mathbf{3}$ and the Roche compound $\mathbf{5}$ constitute highly potent renin inhibitors. A Merck $\beta$-secretase inhibitor 4 .

Most currently used asp-protease inhibitors comprise the statine motif or a derivative thereof. The secondary hydroxyl group therein comprises a transition state mimic of the cleavable bond of the substrate. Associated with this motif is their often peptoid character enriched with several stereochemical centers. Consequently, current asp-protein inhibitors are complex molecules only accessible via multi-step sequential synthesis. ${ }^{7}$ However, peptoid compounds are often disadvantageous due to their potentially limited oral bioavailability and their excessive production costs. e.g. the high production cost of HIV protease inhibitors is one of the reasons for the inaccessibility of these life saving drugs for patients in developing countries.

One of us discovered simple 3,4-disubstituted piperidines as renin inhibitors, which could be subsequently structurally characterized binding to renin. ${ }^{8}$ An optimized analogue is currently undergoing clinical evaluation. Interestingly, it was found that binding of these substituted piperidine derivatives is accompanied by a major induced-fit adaptation around the enzyme's active site (Figure 2). ${ }^{9}$ 


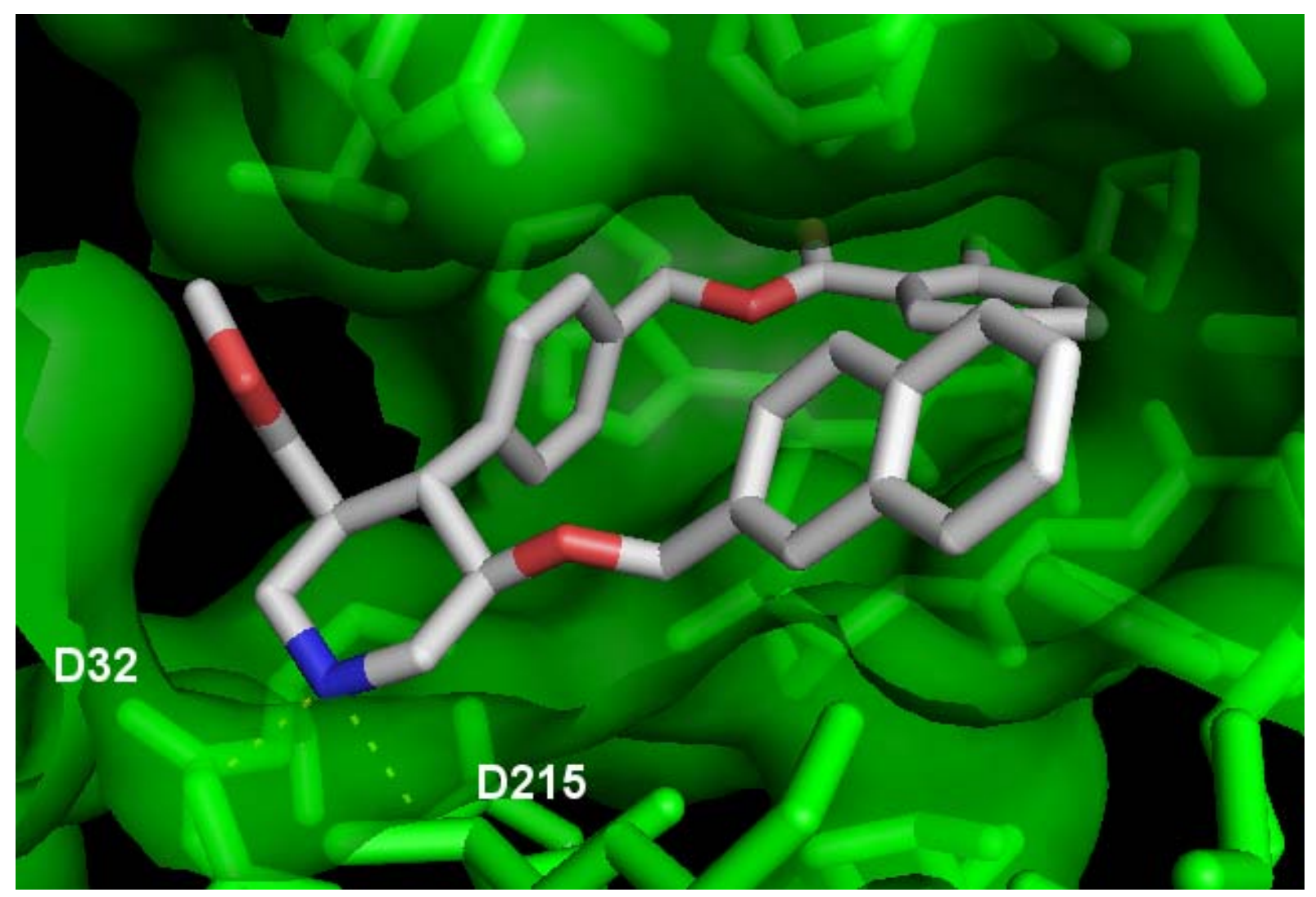

Figure 2. Binding of a Roche piperidine 5 into the active site of renin (pdb id: 1PR8). Grey stick representation of Roche's piperidine renin inhibitor $\mathbf{5}$ and the renin binding groove as green transparent surface. The piperidine NH binds to the two active site aspartic acids D32 and D215. The hydrogen bonds are indicated with doted lines. The picture was generated using PyMol (www.pymol.com).

These structural changes induced by piperidines provide the basis for a novel paradigm for inhibition of monomeric aspartic proteinases. However these results led only to renin inhibitors in the past. ${ }^{10}$ As a continuation of our interest in asp-protease inhibitors we herein present the combinatorial synthesis of a novel class of inhibitors not based on peptidic molecules. ${ }^{11}$

\section{Results}

Based on the investigation of asp-protease inhibitor complexes available we chose the piperidine moiety as an anchor to mimic the water in the active site (Scheme 1). 


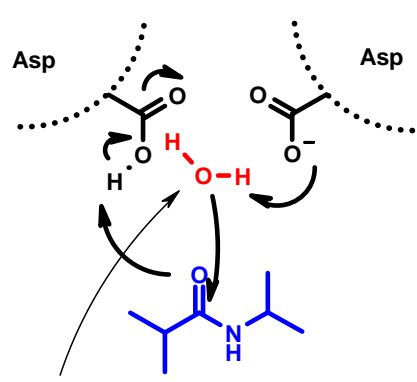

catalytic water Substrat

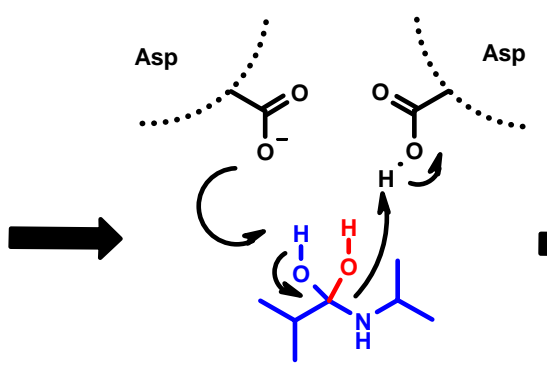

tetrahedral transition state

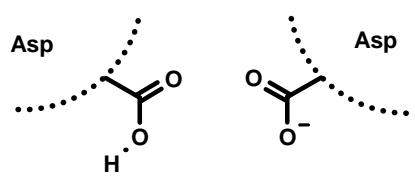<smiles>CC(C)C(=O)O</smiles>

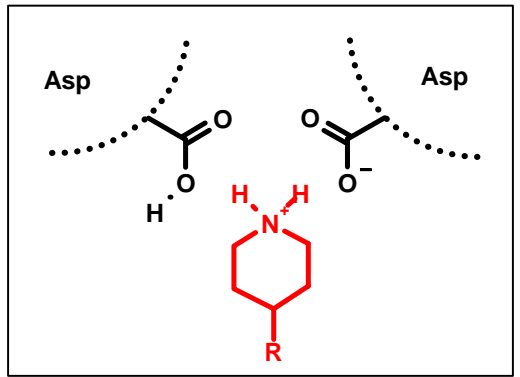

Scheme 1. Asp-protease substrate cleavage mechanism as a guiding design principle for new asp-protease inhibitors. Above: Simplified scheme of the cleavage of an amide bond by the active side water, including the formation of a tetrahedral aminodiol as high energy intermediate. Below: the piperidine ring between the two asp inhibits the mechanism, acting as a water mimetic fixed in the active side.

Another requirement for our design was a fast, diverse and efficient access to the potential corresponding asp-inhibitors. Thus, we chose multi component reaction chemistry, which ideally fulfils these requirements. Multi component reactions (MCR) are reactions with more than two starting materials yielding a defined product comprising most of the parts of the educts. An especial proliferate group of MCRs are isocyanide-based MCRs (IMCRs). They presently account for most of the MCR scaffolds described. ${ }^{12}$

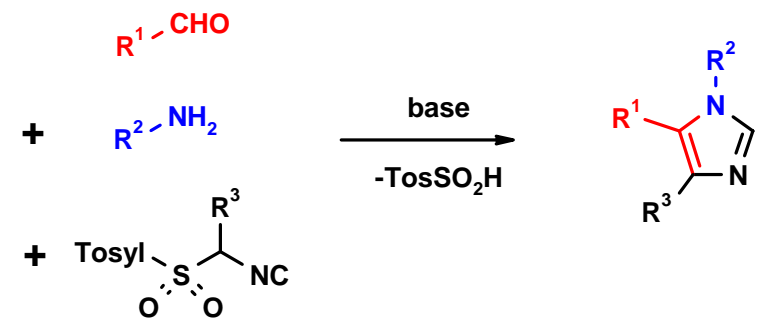

Scheme 2. The general reaction scheme of the vL-imidazole reaction. 
The investigation of the multiple reactivities of Tosmic ( $p$-toluenesulfonylmethyl isocyanide) led van Leusen to discover his vL-3CR in $1977 .{ }^{13,14}$ Tosmics are $\alpha$-acidic, undergo $\alpha$-addition of nucleophiles and electrophiles toward the isocyanide $\mathrm{C}$ and are substrates for radical reactions. In recent years the vL-3CR has become quite popular due to its multi component reaction character and the possible large number of products. The 1,4,5-trisubstituted imidazole scaffold obeys nicely the so-called Pfizer rules for improved oral absorption and cell permeability. The scaffold does not contain amide bonds as opposed to backbones formed by some other IMCRs. Several compounds based on this scaffold have entered clinical trials ${ }^{15}$. In depth investigations by Sisko from SmithKline Beecham indicated that the scope of this reaction is much greater than realized before. ${ }^{16}$ Many unprotected functional groups in the starting materials are compatible with the reaction conditions, including carboxylic acid, ketone, aldehyde, alcohol, amine, azide and alkyne moieties, and can thus provide valuable functionalized intermediates. Moreover, several subsequent reactions following the vL-3CR have been described giving access to even more diverse products, including triazolo-imidazoles by azide-alkyne cycloaddition ${ }^{17}$, imidazo azepine by enyne metathesis ${ }^{18}$, imidazo-pyridine and -azepine by Heck reaction ${ }^{19}$ and other fused imidazoles. $^{20,21}$

Moreover, $\alpha$-substituted Tosmics can be synthesized easily in a large diversity on a multi gram scale. One specific Tosmic derivative for the production of a p38 inhibitor in phase III clinical trails has been described even on a $500 \mathrm{~kg}$ scale. ${ }^{22}$ Gratifyingly, Tosmic and its derivatives are solids and devoid of the otherwise characteristic isocyanide odor. However, the chemistry of Tosmic is much more broadly usable than for the synthesis of imidazoles alone. Other heterocycles, including pyrroles and oxazoles, are also amenable. ${ }^{23}$ The importance of the Tosmic chemistry is emphasized by the commercial availability of several hundred Tosmic derivatives. $^{24}$

Combinatorial generation of large libraries of $\mathrm{vL}-3 \mathrm{CR}$ imidazoles has been described recently by us and is also used in this project. ${ }^{25}$ Briefly, the corresponding starting materials were mixed together in 96 deep well plates (polypropylene) in DMF using 2 eq of $\mathrm{K}_{2} \mathrm{CO}_{3}$ as a base. After shaking for $24 \mathrm{~h}$, the solvent was removed in a vacuum centrifuge and the corresponding products were purified by HPLC. According to this general procedure we could synthesize several libraries around different motifs, each containing several thousand compounds. For the synthesis of an imidazole library containing the piperidine anchor we reacted 4-amino piperidine as an amine component. Gratifyingly, the reaction was compatible with a secondary amine and chemoselective reaction at the primary amine was observed. However, for the resynthesis of large quantities of hits from biological screening we found it to be more convenient to use $1-N$ Boc-4-amino piperidine as starting material for the $\mathrm{vL}-3 \mathrm{CR}$, to purify the intermediate vLproduct and to remove quantitatively the protecting group using TFA/DCM.

For one compound, viz. 7, we were able to obtain diffraction crystals to confirm the two and three dimensional structure (Figure 3). 

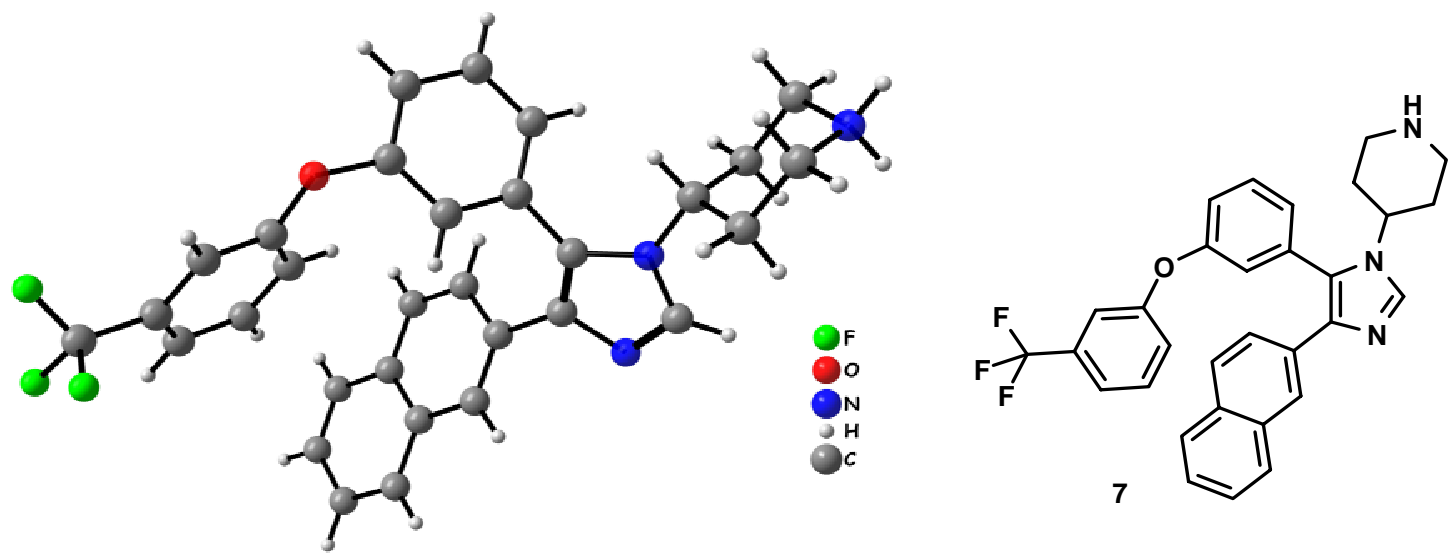

Figure 3. X-ray structure of 4-\{4-Naphthalen-2-yl-5-[3-(3-trifluoromethyl-phenoxy)-phenyl]imidazol-1-yl $\}$-piperidine 7 as triflate salt.*

Representative examples of compounds, both Boc-protected and unprotected products designed to be asp-protease inhibitors and containing the piperidine anchor, are shown in Scheme 3.

In summary, we have designed a novel asp-protease inhibitor scaffold by computational modelling using IMCR. Based on these modelling hypotheses, we synthesized large arrays of 1,3,4-trisubstituted 1-(4-piperidyl)-imidazoles by employing van Leusen's IMCR of $\alpha$ substituted TOSMICs, aldehydes and 4-aminopiperidine. Thus, we prepared more than 40 new TOSMIC derivatives which served as one type of starting material. ${ }^{25}$ This three component reaction is suitable for the rapid synthesis of thousands of imidazoles and several new and exemplary imidazoles are explicitly described. Based on other imidazoles under development, compounds of this scaffold are potentially orally bioavailable. Other advantages are their short and straight forward one-pot synthesis and the lack of any scaffold-intrinsic stereocenter.

Biological screening results of libraries of 1,3,4-trisubstituted 1-(4-piperidyl)-imidazoles and the design process will be reported in due course.

\footnotetext{
* The crystals of 7 are insufficient for a high quality X-ray structure analysis. One trifluoracetate ion is completely disordered. Several hydrogens could not be located. Therefore the data have not been sent to the CCDC.
} 

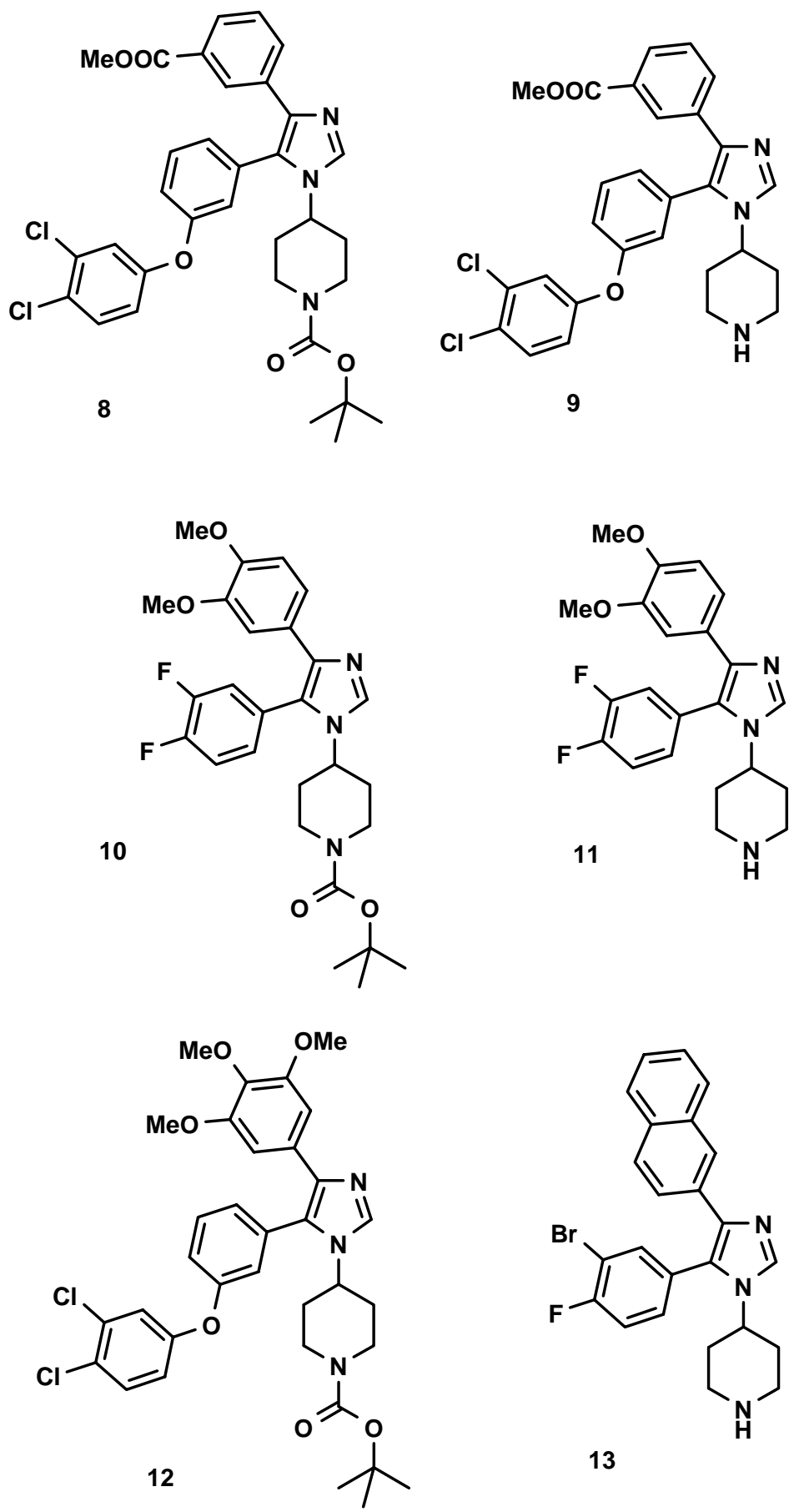

Scheme 3. Representative $\mathrm{vL}-3 \mathrm{CR}$ imidazoles as asp-protease inhibitors containing the piperidine anchor. 


\section{Experimental Section}

General Procedures. Proton and carbon $\mathrm{nmr}$ spectra were obtained in $\mathrm{CDCl}_{3}$ or $\mathrm{CD}_{3} \mathrm{OD}$ and determined with a Mercury 400 spectrometer. Chemical shifts are expressed in ppm $(\delta)$ with respect to TMS as an internal standard. Electrospray ionisation mass spectra (ESI) were obtained using a MSD (Hewlett-Packards HPLC 1100 driven electrospray MS instrument). Products were purified by preparative chromatography with silica gel and ethylacetate as eluent. The purity was determined utilizing a Hewlett-Packard LC 1100 system using a YMC column, 2 mm x $50 \mathrm{~mm}$, $3 \mu \mathrm{m}$ ODS-A, detection wave length at 220 and $254 \mathrm{~nm}$; flow: 0,6 ml/min., with a $6 \mathrm{~min}$. gradient from $90 \% \mathrm{H}_{2} \mathrm{O}$ to $10 \% \mathrm{H} 2 \mathrm{O}\left(0,5 \% \mathrm{CH}_{3} \mathrm{COOH}\right)$ vs. $\mathrm{CH}_{3} \mathrm{CN}$. Preparative HPLC was performed on a Labomatic System, using a Grom Sil 120 ODS-4 HE column $(10 \mu \mathrm{M}, 100$ x 30 $\mathrm{mm}$ ) with a $45 \mathrm{~min}$. methanol/water gradient (30-100\% $\mathrm{MeOH})$ with single wavelength detection at $254 \mathrm{~nm}$, flow $150 \mathrm{ml} / \mathrm{min}$. All products where characterized by $\mathrm{nmr}$ and high resolution mass spectroscopy.

\section{General procedure for resynthesis}

Aldehyde $(1 \mathrm{mmol})$ and $1 \mathrm{mmol} \mathrm{4}$-amino-piperidine-1-carboxylic acid tert-butyl ester $(200 \mathrm{mg})$ are solubilized in $5 \mathrm{ml}$ methanol and stirred for $30 \mathrm{~min} .1 \mathrm{mmol}$ TosMIC derivative and $1 \mathrm{mmol}$ triethylamine $(102 \mathrm{mg}, 140 \mu \mathrm{l})$ are added and the suspension is refluxed for $4 \mathrm{~h}$ and allowed to stir overnight at room temperature. In some cases the product precipitates and can be used in the next step after filtration, otherwise the solvent is evaporated and the product isolated by column chromatography or preparative HPLC. To remove the Boc protection group the imidazole is solubilised in $1 \mathrm{ml} \mathrm{CH}_{2} \mathrm{Cl}_{2}$ and $1 \mathrm{ml}$ TFA are added. The mixture is stirred for $1 \mathrm{~h}$ at room temperature, evaporated and dried under high vacuum to yield the final deprotected product.

\section{4-\{4-Naphthalen-2-yl-5-[3-(3-trifluoromethyl-phenoxy)-phenyl]-imidazol-1-yl\}-piperidine}

(7). $1 \mathrm{mmol} 3$-(3-Trifluoromethyl-phenoxy)-benzaldehyde $(266 \mathrm{mg}, 207 \mu \mathrm{l})$ and $1 \mathrm{mmol} \mathrm{4-}$ amino-piperidine-1-carboxylic acid tert-butyl ester $(200 \mathrm{mg}$ ) are solubilised in $5 \mathrm{ml}$ methanol and stirred for $30 \mathrm{~min} .1 \mathrm{mmol} 2$-[isocyano-(toluene-4-sulfonyl)-methyl]-naphthalene (321 mg) and $1 \mathrm{mmol}$ triethylamine $(102 \mathrm{mg}, 140 \mu \mathrm{l})$ are added and the suspension is refluxed for $4 \mathrm{~h}$ and allowed to stir overnight at room temperature. The precipitate is filtered and used directly in the

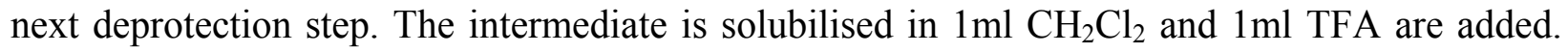
The mixture is stirred for $1 \mathrm{~h}$ at room temperature, evaporated and dried under high vacuum to yield compound 7 (154 mg, 30\%)

$\mathrm{C}_{31} \mathrm{H}_{26} \mathrm{~F}_{3} \mathrm{~N}_{3} \mathrm{O}$ MW $513.55 \mathrm{~g} / \mathrm{mol}$; HRMS (ESI-TOF) $\mathrm{m} / \mathrm{z}=514.2339$ [M-H]+; calc. 514.2107 ${ }^{1} \mathrm{H}-\mathrm{NMR}\left(\mathrm{CDCl}_{3}, 600 \mathrm{MHz}\right): \delta=1.86-1.98(4 \mathrm{H}, \mathrm{m}), 2.55-2.63(3 \mathrm{H}, \mathrm{m}), 3.16-3.18(2 \mathrm{H}, \mathrm{m}), 3.81-$ 3.86 $(1 \mathrm{H}, \mathrm{m}), 6.96-7.04(2 \mathrm{H}, \mathrm{m}), 7.15-7.27(5 \mathrm{H}, \mathrm{m}), 7.37-7.40(2 \mathrm{H}, \mathrm{m}), 7.50-7.52(2 \mathrm{H}, \mathrm{m}), 7.67-$ $7.68(2 \mathrm{H}, \mathrm{m}), 7.74-7.75(2 \mathrm{H}, \mathrm{m}), 7.92(1 \mathrm{H}, \mathrm{s}) .{ }^{13} \mathrm{C}-\mathrm{NMR}\left(\mathrm{CDCl}_{3}, 100 \mathrm{MHz}\right): \delta=34.5,45.7$, $53.3,115.3,115.4,120.0,120.1,120.2,121.6,121.8,122.7,124.5,125.4,125.5,125.6,125.9$, $126.6,127.5,127.6,128.0,130.4,131.0,131.8,132.2,132.3,132.4,132.9,133.5,134.4,138.3$, $156.9,157.3$. 


\section{4-[5-[3-(3,4-Dichloro-phenoxy)-phenyl]-4-(3-methoxycarbonyl-phenyl)-imidazol-1-yl]-} piperidine-1-carboxylic acid tert-butyl ester (8). A mixture of 2 mmol 3-(3,4-dichlorophenoxy)-benzaldehyde $(534 \mathrm{mg}, 386 \mu \mathrm{l})$ and $2 \mathrm{mmol}$ 4-amino-piperidine-1-carboxylic acid tertbutyl ester $(400 \mathrm{mg})$ are solubilised in $5 \mathrm{ml}$ methanol and stirred for $30 \mathrm{~min} .1 \mathrm{mmol} \mathrm{3-}$ [Isocyano-(toluene-4-sulfonyl)-methyl]-benzoic acid methyl ester $(658 \mathrm{mg})$ and $1 \mathrm{mmol}$ triethylamine $(204 \mathrm{mg}, 280 \mu \mathrm{l}$ ) are added and the suspension is refluxed for $4 \mathrm{~h}$. Another $5 \mathrm{ml}$ $\mathrm{MeOH}$ are added to solve the precipitate and the mixture is allowed to stir overnight at room temperature. The precipitate is filtered off and dried in vacuo to yield compound 8 (1050 $\mathrm{mg}$, 84\%) $\mathrm{C}_{33} \mathrm{H}_{33} \mathrm{Cl}_{2} \mathrm{~N}_{3} \mathrm{O}_{5} \mathrm{MW} 622.55 \mathrm{~g} / \mathrm{mol}$; HPLC-MS (ESI-TOF): $\mathrm{tR}=4.37 \mathrm{~min}$.; $\mathrm{m} / \mathrm{z}=622$ [M$\mathrm{H}]+, 646[\mathrm{M}-\mathrm{Na}]+;{ }^{1} \mathrm{H}-\mathrm{NMR}\left(\mathrm{CDCl}_{3}, 400 \mathrm{MHz}\right): \delta=1.46(9 \mathrm{H}, \mathrm{s}), 1.83-1.96(4 \mathrm{H}, \mathrm{m}), 2.65(2 \mathrm{H}$, $\mathrm{m}), 3.84(4 \mathrm{H}, \mathrm{m}), 4.22(2 \mathrm{H}, \mathrm{m}), 6.83-7.19(5 \mathrm{H}, \mathrm{m}), 7.30-7.34(2 \mathrm{H}, \mathrm{m}), 7.51-7.55(1 \mathrm{H}, \mathrm{m}), 7.68-$ $7.72(2 \mathrm{H}, \mathrm{m}), 7.82-7.84(1 \mathrm{H}, \mathrm{m}), 8.01(1 \mathrm{H}, \mathrm{s}) ;{ }^{13} \mathrm{C}-\mathrm{NMR}\left(\mathrm{CDCl}_{3}, 100 \mathrm{MHz}\right): \delta=28.4,33.4$, $51.9,53.3,80.1,118.1,120.1,120.3,121.5,126.5,127.0,127.5,127.6,128.3,130.0,130.8$, $131.1,131.2,132.5,133.3,133.9,134.4,137.4,154.4,156.0,157.0,166.9$.

3-\{5-[3-(3,4-Dichloro-phenoxy)-phenyl]-1-piperidin-4-yl-1H-imidazol-4-yl\}-benzoic acid methyl ester (9). 1000 mg (1.6 mol) 4-[5-[3-(3,4-Dichloro-phenoxy)-phenyl]-4-(3methoxycarbonyl-phenyl)-imidazol-1-yl]-piperidine-1-carboxylic acid tert-butyl ester 8 are solubilised in $1 \mathrm{ml} \mathrm{CH}_{2} \mathrm{Cl}_{2}$ and $1 \mathrm{ml}$ TFA are added. The mixture is stirred for at room temperature and followed by TLC. After completion the solvent is evaporated and dried under high vacuum to yield compound 9 ( $820 \mathrm{mg}, 98 \%) \mathrm{C}_{28} \mathrm{H}_{25} \mathrm{Cl}_{2} \mathrm{~N}_{3} \mathrm{O}_{3} \mathrm{MW} 522.43 \mathrm{~g} / \mathrm{mol}$; HPLC-MS (ESI-TOF): tR $=3.35 \mathrm{~min} . ; \mathrm{m} / \mathrm{z}=522[\mathrm{M}-\mathrm{H}]+;{ }^{1} \mathrm{H}-\mathrm{NMR}\left(\mathrm{CDCl}_{3}, 400 \mathrm{MHz}\right): \delta=2.23(2 \mathrm{H}, \mathrm{m})$, 2.42-2.45 (2H, m), $3.09(2 \mathrm{H}, \mathrm{m}), 3.56-3.59(2 \mathrm{H}, \mathrm{m}), 3.78(3 \mathrm{H}, \mathrm{s}), 4.35(1 \mathrm{H}, \mathrm{m}), 6.73-7.54(9 \mathrm{H}$, m), 7.87-7.96 $(2 \mathrm{H}, \mathrm{m}), 8.28(1 \mathrm{H}, \mathrm{m}), 8.57(1 \mathrm{H}, \mathrm{m}) ;{ }^{13} \mathrm{C}-\mathrm{NMR}\left(\mathrm{CDCl}_{3}, 100 \mathrm{MHz}\right): \delta=29.0,30.4$, 43.4, 46.6, 52.6, 113.7, 116.6, 118.8 120.6, 121.3, 121.6125 .6 125.7, 127.9, 128.7, 129.6, 131.2, $131.6,132.5,133.6,155.2,158.3,160.6,161.0,166.6$.

4-[5-(3,4-Difluoro-phenyl)-4-(3,4-dimethoxy-phenyl)-imidazol-1-yl]-piperidine-1-carboxylic acid tert-butyl ester (10). A mixture of $1 \mathrm{mmol}$ 3,4-Difluoro-benzaldehyde (142 $\mathrm{mg}, 110 \mu \mathrm{l})$ and $1 \mathrm{mmol} 4$-amino-piperidine-1-carboxylic acid tert-butyl ester $(200 \mathrm{mg})$ are solubilised in $5 \mathrm{ml}$ methanol and stirred for $30 \mathrm{~min} .1 \mathrm{mmol}$ 4-[isocyano-(toluene-4-sulfonyl)-methyl]-1,2dimethoxy-benzene $(331 \mathrm{mg})$ and $1 \mathrm{mmol}$ triethylamine $(102 \mathrm{mg}, 140 \mu \mathrm{l})$ are added and the suspension is refluxed for $4 \mathrm{~h}$ and allowed to stir overnight at room temperature. The precipitate is filtered to yield compound $10(170 \mathrm{mg}, 34 \%) \mathrm{C}_{27} \mathrm{H}_{40} \mathrm{FN}_{3} \mathrm{O}_{4} \mathrm{MW} 499.56 \mathrm{~g} / \mathrm{mol}$; HPLC-MS (ESI-TOF): tR $=3.16 \mathrm{~min} . ; \mathrm{m} / \mathrm{z}=500[\mathrm{M}-\mathrm{H}]+, 524$ [M-Na]+; ${ }^{1} \mathrm{H}-\mathrm{NMR}\left(\mathrm{CDCl}_{3}, 400 \mathrm{MHz}\right): \delta=$ $1.45(9 \mathrm{H}, \mathrm{s}), 1.82-1.86(2 \mathrm{H}, \mathrm{m}), 1.94-1.97(2 \mathrm{H}, \mathrm{m}), 2.63(2 \mathrm{H}, \mathrm{m}), 3.72(3 \mathrm{H}, \mathrm{s}), 3.95(4 \mathrm{H}, \mathrm{m})$, $4.21(2 \mathrm{H}, \mathrm{m}), 6.68(1 \mathrm{H}, \mathrm{d}), 6.69(1 \mathrm{H}, \mathrm{m}), 6.80-6.98(3 \mathrm{H}, \mathrm{m}), 7.17(1 \mathrm{H}, \mathrm{s}), 7.75(1 \mathrm{H}, \mathrm{s}) .{ }^{13} \mathrm{C}-\mathrm{NMR}$ $\left(\mathrm{CDCl}_{3}, 100 \mathrm{MHz}\right): \delta=28.4,33.5,53.1,55.6,55.73,55.9,56.1,80.1,109.6,110.8,111.6,113.8$, 118.6, 123.6, 133.1.

4-[5-(3,4-Difluoro-phenyl)-4-(3,4-dimethoxy-phenyl)-imidazol-1-yl]-piperidine (11). $170 \mathrm{mg}$ (0.34 mol) 4-[5-(3,4-Difluoro-phenyl)-4-(3,4-dimethoxy-phenyl)-imidazol-1-yl]-piperidine-1carboxylic acid tert-butyl ester 10 is solubilized in $1 \mathrm{ml} \mathrm{CH}_{2} \mathrm{Cl}_{2}$ and $1 \mathrm{ml}$ TFA are added. The 
mixture is stirred for $1 \mathrm{~h}$ at room temperature, evaporated and dried under high vacuum to yield compound 11 (113 mg, 84\%) $\mathrm{C}_{22} \mathrm{H}_{23} \mathrm{~F}_{2} \mathrm{~N}_{3} \mathrm{O}_{2}$ MW $399.44 \mathrm{~g} / \mathrm{mol}$; HPLC-MS (ESI-TOF): tR = $2.50 \mathrm{~min} . ; \mathrm{m} / \mathrm{z}=424$ [M-Na]+; ${ }^{1} \mathrm{H}-\mathrm{NMR}\left(\mathrm{CD}_{3} \mathrm{OD}, 400 \mathrm{MHz}\right): \delta=2.18(2 \mathrm{H}, \mathrm{m}), 2.42(2 \mathrm{H}, \mathrm{m})$, $2.96(2 \mathrm{H}, \mathrm{m}), 3.50-3.85(8 \mathrm{H}, \mathrm{m}), 4.27(1 \mathrm{H}, \mathrm{m}), 6.65-6.97(5 \mathrm{H}, \mathrm{m}), 8.87(1 \mathrm{H}, \mathrm{m}), 9.05(1 \mathrm{H}, \mathrm{m})$. ${ }^{13} \mathrm{C}-\mathrm{NMR}\left(\mathrm{CD}_{3} \mathrm{OD}, 100 \mathrm{MHz}\right): \delta=28.9,43.2,52.2,55.5,55.7,55.8,55.9,110.0,111.3,112.0$, $112.1,113.0,116.8,118.3,120.0,123.7,128.5,131.1,149.0,149.9,150.1,151.2$.

\section{4-[5-[3-(3,4-Dichloro-phenoxy)-phenyl]-4-(3,4,5-trimethoxy-phenyl)-imidazol-1-yl]-} piperidine-1-carboxylic acid tert-butyl ester (12). A mixture of $0.5 \mathrm{mmol} 3$-(3,4-dichlorophenoxy)-benzaldehyde (134 $\mathrm{mg}, 99 \mu \mathrm{l})$ and $0.5 \mathrm{mmol} \mathrm{4-amino-piperidine-1-carboxylic} \mathrm{acid}$ tert-butyl ester $(100 \mathrm{mg})$ are solubilized in $5 \mathrm{ml}$ methanol and stirred for $30 \mathrm{~min} .0 .5 \mathrm{mmol} \mathrm{5-}$ [Isocyano-(toluene-4-sulfonyl)-methyl]-1,2,3-trimethoxy-benzene $(181 \mathrm{mg})$ and $0.5 \mathrm{mmol}$ triethylamine $(51 \mathrm{mg}, 70 \mu \mathrm{l})$ are added and the suspension is refluxed for $4 \mathrm{~h}$ and allowed to stir overnight at room temperature. The precipitate is filtered to yield compound 12 (133 $\mathrm{mg}, 20 \%)$ $\mathrm{C}_{34} \mathrm{H}_{37} \mathrm{Cl}_{2} \mathrm{~N}_{3} \mathrm{O}_{6} \mathrm{MW} 654.60 \mathrm{~g} / \mathrm{mol}$; HPLC-MS (ESI-TOF): $\mathrm{tR}=4.21 \mathrm{~min}$; $\mathrm{m} / \mathrm{z}=654$ [M-H]+, $678[\mathrm{M}-\mathrm{Na}]+;{ }^{1} \mathrm{H}-\mathrm{NMR}\left(\mathrm{CDCl}_{3}, 400 \mathrm{MHz}\right): \delta=1.43(9 \mathrm{H}, \mathrm{s}), 1.79-1.94(4 \mathrm{H}, \mathrm{m}), 2.63(2 \mathrm{H}, \mathrm{m})$, $3.61(6 \mathrm{H}, \mathrm{s}), 3.78-3.82(4 \mathrm{H}, \mathrm{m}), 4.21(2 \mathrm{H}, \mathrm{m}), 6.64(2 \mathrm{H}, \mathrm{m}), 6.67-6.79(1 \mathrm{H}, \mathrm{m}), 6.95-7.00(2 \mathrm{H}$, $\mathrm{m}), 7.09-7.16(2 \mathrm{H}, \mathrm{m}), 7.32-7.34(1 \mathrm{H}, \mathrm{m}), 7.47-7.51(1 \mathrm{H}, \mathrm{m}), 7.67(1 \mathrm{H}, \mathrm{s}) .{ }^{13} \mathrm{C}-\mathrm{NMR}\left(\mathrm{CDCl}_{3}\right.$, $100 \mathrm{MHz}): \delta=28.2,33.3,53.2,55.5,60.7,80.0,103.6,118.1,119.5,120.3,121.3,126.5,126.6$, $127.1,129.2,130.9,131.1,132.8,133.2,133.5,136.6,137.8,152.8,154.2,155.6,156.9$.

4-[5-(3-Bromo-4-fluoro-phenyl)-4-naphthalen-2-yl-imidazol-1-yl]-piperidine (13). A mixture of 1 mmol 3-bromo-4-fluoro-benzaldehyde (203 $\mathrm{mg})$ and 1mmol 4-amino-piperidine-1carboxylic acid tert-butyl ester $(200 \mathrm{mg}$ ) are solubilized in $5 \mathrm{ml}$ methanol and stirred for $30 \mathrm{~min}$. 1 mmol 2-[Isocyano-(toluene-4-sulfonyl)-methyl]-naphthalene $(321 \mathrm{mg})$ and $1 \mathrm{mmol}$ triethylamine $(102 \mathrm{mg}, 140 \mu \mathrm{l})$ are added and the suspension is refluxed for $4 \mathrm{~h}$ and allowed to stir overnight at room temperature. The precipitate is filtered and used directly in the next deprotection step. The intermediate is solubilised in $1 \mathrm{ml} \mathrm{CH}_{2} \mathrm{Cl}_{2}$ and $1 \mathrm{ml}$ TFA are added. The mixture is stirred for $1 \mathrm{~h}$ at room temperature, evaporated and dried under high vacuum to yield compound 13 (376 mg, 84\%) $\mathrm{C}_{24} \mathrm{H}_{21} \mathrm{BrFN}_{3}$ MW $450.35 \mathrm{~g} / \mathrm{mol}$; HPLC-MS (ESI-TOF): tR = 2.98 $\min$; $\mathrm{m} / \mathrm{z}=452[\mathrm{M}-\mathrm{H}]+;{ }^{1} \mathrm{H}-\mathrm{NMR}\left(\mathrm{CDCl}_{3}, 400 \mathrm{MHz}\right): 1.81-1.88(\mathrm{~m}, 2 \mathrm{H}), 2.22-2.33(\mathrm{~m}, 2 \mathrm{H})$,

2,48-2.54 (m, 2H), 3.10-3.13 (m, 2H), $3.66(\mathrm{~m}, 1 \mathrm{H}), 7.10-7.90(\mathrm{~m}, 11 \mathrm{H}) .{ }^{13} \mathrm{C}-\mathrm{NMR}\left(\mathrm{CDCl}_{3}, 100\right.$ MHz): $34.8 ; 46.2 ; 53.6 ; 53.5,110.3,110.1 ; 117.5 ; 117.7 ; 125.2 ; 125.6 ; 126.2 ; 127.7 ; 128.3$; $131.7 ; 132.5 ; 133.7 ; 134.8 ; 136.1 ; 138.8 ; 160.01\left(\mathrm{~d},{ }^{1} \mathrm{~J}(\mathrm{CF})=250 \mathrm{~Hz}\right)$.

\section{References}

1. O’Brien, E. Expt. Opin. Invest. Drugs 2006, 15, 1269.

2. Burlet, S.; Pietrancosta, N.; Laras, Y.; Garino, C.; Quelever, G.; Kraus, J. L. Curr. Phram. Des. 2005, 11, 3077.

3. Vassar, R. Adv. Drug. Deliv. Rev. 2002, 54, 1589. 
4. Douglas, L. J. Crit. Rev. Biotechnol. 1988, 8, 121.

5. Liaudet-Coopman, E.; Beaujouin, M.; Derocq, M. Garcia, D.; Glondu-Lassis, M.; Laurent-Matha, V.; Prébois, C.; Rochefort, H.; Vignon, F. Canc. Lett. 2006, 237, 167.

6. Coombs, G. H.; Goldberg, D. E.; Klemba, M.; Berry, C.; Kay, J.; Mottram, J. C. Trends Parasitol 2001, 17, 532.

7. Izawa, K.; Onishi, T. Chem. Rev. 2006, 126, 2811.

8. Vieira, E.; Binggeli, A.; Breu, V.; Bur, D.; Fischli, W.; Guller, R.; Hirth, G.; Marki, H., P.; Muller, M., Oefner, C., Scalone, M., Stadler, H.; Wilhelm, M.; Wostl, W. Bioorg. Med. Chem. Lett. 1999, 10, 1397.

9. Oefner, C., Binggeli, A.; Breu, V.; Bur, D.; Clozel, J.-P.; D’Arcy, A.; Dorn, A.; Fischli, W.; Grüninger, F.; Güller, R.; Hirth, G.; Märki, H., P.; Mathews, S.; Müller, M.; Ridley, R., G.; Stadler, H.; Viera, E.; Wilhelm, M.; Winkler, F., K.; Wostl, W. Chem. Biol. 1999, $6,127$.

10. Rich, D. H.; Bursavich, M. G.; West, C. W. Org. Lett. 2001, 3, 2317.

11. Yehia, N.A.M.; Antuch, W.; Beck, B.; Hess, S.; Schauer-Vukasinovic, V.; Almstetter, M.; Furer, P.; Dömling, A. Bioorg. Med. Chem. Lett. 2004, 14, 3121.

12. Dömling, A. Chem. Rev. 2006, 126, 17.

13. van Leusen, A. M.; Wildeman, J.; Oldenziel, O. H. J. Org. Chem. 1977, 42, 1153.

14. van Leusen, D.; van Leusen, A. M. Org. React. 2003, 57, 419.

15. P38 inhibitor: Sisko, J.; Mellinger, M.; Sheldrake, P. W.; Baine, N. H. Tetrahedron Lett. 1996, 37, 8113.

16. Sisko, J.; Mellinger, M.; Sheldrake, P. W.; Baine, N. H. Org. Synth. 2000, 77, 198.

17. Garcias, V.; Darczak, D.; Gasiecki, A. F.; Djuric, S. W. Tetrahedron Lett. 2005, 46, 9053.

18. Garcias, V.; Gasiecki, A. F.; Djuric, S. W. Tetrahedron Lett. 2005, 46, 9049.

19. Beebe, X.; Garcias, V.; Djuric, S. W. Tetrahedron Lett. 2006, 47, 3225.

20. Garcias, V.; Gasiecki, A. F.; Pagano, T. G.; Djuric, S. W. Tetrahedron Lett. 2006, 47, 8873.

21. Gracias, V.; Gasiecki, A. F.; Djuric, S. W. Org. Lett. 2005, 7, 3183.

22. Sisko, J.; Mellinger, M. Pure Appl. Chem. 2002, 74, 1349.

23. Dömling, A., Org. Chem. Highlights 2005, May 5. URL: http://www.organicchemistry.org/Highlights/2005/05May.shtml

24. See e.g. www.synthatex.com.

25. Beck, B. A.; Leppert, C. A.; Mueller, B. K.; Dömling, A. QSAR 2006, 25, 527. 